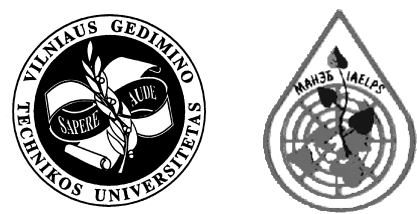

JOURNAL OF ENVIRONMENTAL ENGINEERING AND LANDSCAPE MANAGEMENT

http:/www.vtu.lt/english/editions

2005, Vol XIII, No 2, 103-107

Paper reviene

\title{
IONIZING RADIATION IN BUILDINGS: SITUATION AND DEALING WITH PROBLEMS
}

\author{
Donatas Butkus ${ }^{1}$, Gendrutis Morkūnas ${ }^{2}$, Laima Pilkyte் $\dot{1}^{1,3}$ \\ ${ }^{1}$ Dept of Environmental Protection, Vilnius Gediminas Technical University, \\ Sauletekio al.11, LT-10223Vilnius, Lithuania,E-mail: aak@ap.vtu.lt \\ ${ }^{2}$ Radiation Protection Centre, Kalvariju g. 153, LT-08821Vilnius, Lithuania, E-mail: genmo@takas.lt \\ ${ }^{3}$ Radiation Protection Centre, Kalvariju g. 153,LT-08821Vilnius, Lithuania, E-mail: l.pilkyte@rsc.lt
}

Received 24 Feb 2005; accepted 14 Mar 2005

\begin{abstract}
Among many artificial and natural sources of exposure the exposure which is received indoors is very important both from the point of view of its magnitude and necessity of optimization. Such sources as indoor radon and natural radionuclides in construction materials are the most significant ones. The survey results of national indoor radon show that its concentrations might be rather high in some regions. Construction materials can be a significant source of indoor radon, however, in Lithuania external exposure due to radionuclides in these materials is much more important. Very often natural exposure is neglected from the point of view of radiation protection. Such measures as raising of public awareness, application of radiation protection and construction-related regulations, remedial measures for radon indoors should be taken in solving the problem. Necessity of optimization of protection from radiation indoors is emphasized.
\end{abstract}

Keywords: radiation, natural exposure, indoor radon, construction materials, optimization of radiation protection, remedial measures.

\section{Introduction}

Humans live in a radiation environment. Different sources - both natural and artificial - give exposure which is not only recorded and assessed but also affects people [1]. The degree of this impact (more precisely, the probability of detrimental health effects) depends on dose received, which in turn is related with the strength of a radiation source, type of radiation, pathways of exposure, tissues and organs irradiated, duration of exposure and other parameters.

Ionizing radiation indoors is an important part of the total exposure. This paper deals with the main peculiarities which are responsible for the magnitude of exposure indoors and discusses the most important issues related with optimized protection from this exposure.

\section{Problem formulation}

The fact that people are affected by natural radiation has been known for many years [2]. However, the problem was mainly related with artificial sources of radiation: radionuclides released into the atmosphere during tests of nuclear weapons, fallouts after nuclear accidents, radionuclides used for different purposes in medicine, industry, research and other fields.

The problem of natural exposure, i e exposure from sources, which are not created by human activities, was recognized relatively late. Even then, this problem was not related with an indoor environment. Traditionally, this environment was considered to be safe from the point of view of radiation protection, unless it was affected by artificial radionuclides.

First of all, the problem of enhanced natural radioactivity was recognized in Swedish houses constructed of blue concrete - lightweight concrete with uraniumrich alumn shale [3]. But even then this problem was considered to be site specific - important for Sweden where large numbers of different buildings were constructed of this cheap and easily treated construction material.

However, later studies carried out in different countries soon revealed that indoor radon and radionuclides in construction materials usually constituted the largest part of the total exposure. 
Even after this information became available and was confirmed by many investigations, attention paid to natural exposure, particularly to exposure indoors, is relatively negligible. Despite many efforts made by researchers to inform all potential stakeholders and to create a basis for national strategies directed to decrease of doses and numbers of persons exposed to this source of exposure, society is reluctant to recognize this source as an important one. Much more attention is paid to problems related with releases from nuclear power plants or doses due to radioactive waste, though these sources of exposure are immeasurably smaller than natural ones indoors.

The problem of exposure indoors might be divided into a few ones: unawareness of people about pathways and magnitudes of exposure indoors and its peculiarities, lack of information on remedial measures, reluctance of related bodies, including nongovernmental organizations, trying to protect people from hazards of environment to deal with the problem, difficulties in controlling this exposure and implementing remedial measures.

\section{Magnitude of exposure indoors and its sources}

As it was mentioned above, there are two main sources of exposure indoors.

One more source might be mentioned in this case. It is artificial radionuclides which occasionally are dispersed in an indoor environment, e g sources of ionizing radiation of a high activity, the control of which is lost and which are melted into fabricated parts which are used for construction materials, e g iron rods used for reinforced concrete [4]. Though doses received by people in such cases might be very high, the probability of such cases is rather small and will not be dealt with later in this paper. The most effective way of protection from this type of exposure are preventive measures of source control, i e measures against loosing control over these sources.

Indoor radon and radionuclides in construction materials are the most important sources of exposure indoors.

Measurements of concentrations of indoor radon in randomly selected detached houses in Lithuania in 19951998 revealed regions where the potential for higher indoor radon concentrations is higher in comparison with the average of the whole country. Usually these concentrations are higher in lithological regions with the soil which is more permeable for soil gas containing rather high concentrations of radon. It shows that the main source of indoor radon in Lithuania is the soil [5].

Since transfer of radon into buildings depends on isolation of the interior space of buildings from the soil, the peculiarities of building construction (e $\mathrm{g}$ thickness of an engineering barrier) are important for the concentrations of indoor radon. It is evident that these peculiarities are also significant when selecting and implementing remedial measures.
More detailed investigations of indoor radon situation in Lithuania were started in 2000 . These investigations gave a more precise information about indoor radon situation in regions with a higher indoor radon potential identified during the first survey. Measurements of indoor radon concentrations in multifamily houses have also been performed.

An average concentration of indoor radon in multifamily houses is $(19 \pm 3) \mathrm{Bq} / \mathrm{m}^{3}$, in detached houses it is $(55 \pm 5) \mathrm{Bq} / \mathrm{m}^{3}$. The population weighted average in Lithuania is $(33 \pm 4) \mathrm{Bq} / \mathrm{m}^{3}$. Confidence intervals of two standard deviations are also given.

An average annual effective dose due to indoor radon, presuming that the equilibrium factor indoors is 0,4 , annual occupancy -7000 hours and the dose coefficient - $9 n \mathrm{~Sv} \cdot\left(\mathrm{Bq} \cdot \mathrm{h} \cdot \mathrm{m}^{-3}\right)^{-1}[1]$ is $0,82 \mathrm{mSv}$. It might cause approximately 140 deaths in Lithuania due to cancer initiated by ionizing radiation of radon daughters [2].

From the point of view of magnitude, this source is on average the most important one. This source is also significant outdoors [6].

Another important source of exposure are radionuclides in construction materials. They contain K-40 and the products of decay series of Ra-226 and Th-232, though the traces of decay series of U-238 might be also detected [7].

Investigations of concentrations of natural radionuclides in construction materials produced and/or used in Lithuania show that these concentrations depend on the type of construction materials and might be in a wide range in construction materials even of the same type (Table).

The data given in the Table show that the magnitude of exposure due to radionuclides in construction materials might be different, since it depends on concentrations of radionuclides, i e the strength of a source.

However, other parameters, such as the amount of a construction material used, its distribution in a building, are important for the magnitude of doses. It is taken into account when construction materials, which are to be radiologicaly surveyed, are selected. Classification of construction materials from the point of view of potential exposure might be useful in optimization of measuring radionuclide concentrations.

New construction materials are fabricated using nontraditional raw materials some of which might contain elevated concentrations of natural radionuclides. An example might be phosphogypsum [8]. This fact will be taken into account when construction materials are selected for a radiological survey.

It is found by measurements and calculations that an average annual effective dose indoors due to penetrating radiation is $0,61 \mathrm{mSv}$. According to generally accepted risk coefficients, this exposure might cause around 100 deaths in Lithuania every year.

The largest part of this dose is due to radionuclides in construction materials. Cosmic radiation indoors gives approximately $0,30 \mathrm{mSv}$ per year. 
Concentrations of radionuclides in the most common construction materials in Lithuania. Confidence intervals of two standard deviations are given in average values

\begin{tabular}{|l|c|c|c|c|c|c|}
\hline \multirow{3}{*}{ Material } & \multicolumn{5}{|c|}{ Concentrations, Bq/kg } \\
\cline { 2 - 7 } & \multicolumn{3}{|c|}{ Average } & Range \\
\cline { 2 - 7 } & Ra-226 & Th-232 & K-40 & Ra-226 & Th-232 & K-40 \\
\hline Bricks & $31 \pm 15$ & $20 \pm 9$ & $522 \pm 160$ & $10-84$ & $5-60$ & $228-1140$ \\
\hline Cement & $70 \pm 17$ & $30 \pm 9$ & $268 \pm 48$ & $4-465$ & $3-211$ & $2-1510$ \\
\hline Ceramics & $60 \pm 11$ & $71 \pm 20$ & $1030 \pm 92$ & $9-169$ & $32-426$ & $13-1340$ \\
\hline Clay & $55 \pm 17$ & $52 \pm 25$ & $884 \pm 170$ & $9-114$ & $7-191$ & $225-1280$ \\
\hline Concrete & $37 \pm 10$ & $25 \pm 8$ & $480 \pm 76$ & $6-142$ & $4-110$ & $63-1220$ \\
\hline Expanded clay & $85 \pm 9$ & $62 \pm 7$ & $1135 \pm 114$ & $63-100$ & $47-77$ & $809-1310$ \\
\hline Granite & $37 \pm 9$ & $30 \pm 7$ & $870 \pm 136$ & $5-292$ & $3-141$ & $220-1620$ \\
\hline Sand and gravel & $24 \pm 3$ & $14 \pm 1,2$ & $464 \pm 37$ & $2-67$ & $1-64$ & $1-926$ \\
\hline Wood & $4,8 \pm 2,5$ & $1,9 \pm 1,1$ & $21 \pm 14$ & $2-12$ & $0-4$ & $6-77$ \\
\hline
\end{tabular}

\section{Principles and measures of protection from expo- sure indoors}

In general, the same radiation protection principles are applied when radiation protection measures related with exposure indoors are used [9, 10]. They include justification of exposure and optimization of radiation protection. The third radiation protection principle, namely limitation of doses, is not applied in that particular case because of non irrelevance of it as it regards to natural exposure. Doses of people due to radiation indoors can not be controlled by the same means as it is done in case of practices where radiation sources are used.

The most important principle in this case is optimization of radiation protection which implies that doses received by people and the number of exposed people will be as low as reasonably achievable, social and economic conditions taken into account. This principle originates from two facts related with ionizing radiation linear non-threshold effect-dose relationship and impossibility to achieve a situation when no exposure exists. The above mentioned linear non-threshold effect-dose relationship means that exposure of any magnitude might cause adverse health effects and the probability of these effects depends on dose [2].

Application of the principle of justification (which means that benefit received due to use of something that increases exposure will outweigh detriment caused by ionizing radiation) [2] in the case of exposure indoors is rather straightforward - situations, when exposure due to indoor radon or radionuclides in construction materials are not acceptably high, will be eliminated. In the case of construction materials it means a ban of using construction materials which might cause doses higher than some defined levels.

Application of justification, when it is related with indoor radon is more problematic - people cannot be forbidden to live in their own houses, even if indoor radon concentrations exceed some defined levels. For this reason the Lithuanian legislation sets the following measures in case indoor radon concentrations are higher than the levels given in the legislation: affected people will be aware of the situation and increased risks and will be informed about possible remedial measures. A stricter approach is used for workplaces in buildings with elevated indoor radon concentrations - employers shall take remedial measures which decrease indoor radon concentrations below permitted levels.

The principle of optimization is more difficult to apply. It is always very problematic to define the target values - levels of protection (e $\mathrm{g}$ doses or concentrations of radionuclides) which are to be achieved. Very often an approach common for a number of countries with similar social and economic conditions is used. In this respect Lithuania follows the practices of the European Union. However, as soon as it comes to practical implementation of radiation protection measures (operational radiation protection) new problems arise.

For example, there are different technical remedial and preventive measures elaborated against indoor radon. One of them is radon risk analysis when, on the basis of measurements of radon concentrations and studies of the soil permeability, potential for high radon concentrations indoors is determined, and appropriate measures are recommended [11, 12].

An example of radon risk study might be that performed in Panevėžys development area. Concentrations of radon gas in the soil up to $78 \mathrm{kBq} / \mathrm{m}^{3}$ were detected. The level important in radon risk mapping $-40 \mathrm{kBq} / \mathrm{m}^{3}$ - is exceeded in $25 \%$ of measuring points [13]. It shows that some areas, according to universal principles of radon risk classification, might be classified as areas of a medium or increased radon risk. If an area falls into the class of an increased radon risk, special measures preventing transport of radon into buildings should be used during construction of new buildings.

Application of the principle of optimization is connected with the fact that society is not prepared for perception of risks associated with natural exposure as the risks due to nuclear industry or radioactive waste are perceived. For this reason the measures for protection 
of people from ionizing radiation indoors shall include not only technological ones (directed to decrease exposure by purely technical means) but public information in general and information of concerned people in particular.

Experience shows that awareness of society in problems related with exposure indoors is growing. Different measures, including publications on radon and natural radiation and possible remedial measures, are effective in this regard [3, 14]. On the other hand, all possible means of communication will be used, including measurements of indoor radon concentrations in schools when schoolchildren have a possibility to get acquainted with the problem.

Importance of international co-operation cannot be neglected in this area [15]. Since the problem of natural radiation and radiation indoors is rather complicated from the methodological point of view, joint actions of institutions dealing with the problem in different countries might increase efficiency in finding optimized solutions.

The experience, accumulated in Lithuania since the program related with exposure indoors was started, shows that all these measures should be used as elements of the whole system. Their significance in the system depends on the stage of progress in this field. Measurements and assessment of doses are the most important at the first stage when situation related with internal exposure is unknown. As soon as sufficient information on exposure and its relationships is collected, public information becomes more and more important. Raising public awareness is indicated by increasing interest coming from people. It helps introduction of remedial and preventive measures, if they are needed. During implementation of these measures their efficiency will be checked.

\section{Conclusions}

Natural sources in a living and working environment are important from the point of view of the magnitude of doses and numbers of people affected.

Radiation protection of general population is a rather complicated task. An area related with exposure indoors is even more problematic. Problems arise not only in assessment of exposure and determination of parameters which are important for the magnitude of this exposure, but also in identification and implementation of radiation protection measures. Regulations on limitation of exposure which are effective in many fields of radiation protection are not able to solve all the problems related with exposure indoors. Such measures as public information, training of professionals engaged in construction activities, international co-operation should also be used for achieving tasks of decreasing public exposure down to levels as low as reasonably achievable.

\section{References}

1. UNSCEAR. United Nations Scientific Committee on the Effects of Atomic Radiation UNSCEAR 2000 Report to the General Assembly. Sources, 2000. 654 p.

2. International Commission on Radiological Protection. ICRP Publication 65. Protection against radon-222 at home and at work, 1994. $45 \mathrm{p}$.

3. Clavensjo, B.; Akerblom, G.; Morkūnas, G. The radon book. Measures against radon, 1999. $128 \mathrm{p}$ (in Lithuanian).

4. Hwang, J-Y.; Chang, J.B.H.; Chang, W.P. Spread of ${ }^{60} \mathrm{Co}$ contaminated steel and its legal consequences in Taiwan. Health Physics, 81(6), New York: Lippincot Williams \& Wilkins, 2001, p 622-660.

5. Morkūnas, G. Estimation of the effective dose due to indoor radon in the detached houses. Doctoral thesis, 2000, $96 \mathrm{p}$ (in Lithuanian).

6. Lebedytè, M.; Butkus, D. Equivalent dose rate in the ground-level air caused by the ${ }^{222} \mathrm{Rn}$ progeny gamma radiation. Environmental Engineering (Aplinkos inžinerija), Vol IX, No 3, 2001, p 153-157 (in Lithuanian).

7. O'Brien, R. S,; Aral, H.; Peggie, J. R. Radon exhalation rates and gamma doses from ceramic tiles. Health Physics, 75(64), New York: Lippincot Williams \& Wilkins, 1998, p 630-639.

8. Thomas, P.L. A radiological evaluation of phosphogypsum. Health Physics, 60(5), New York: Lippincot Williams \& Wilkins, 1991, p 691-693.

9. International Atomic Energy Agency. International Basic Safety Standards for Protection against Ionizing Radiation and for the Safety of Radiation Sources. Safety Series No $115,1996.387$ p.

10. International Commission on Radiological Protection. ICRP publication 60. 1990 recommendations of the International Commission on Radiological Protection, Vol 21, 1990. $201 \mathrm{p}$.

11. Miles, J. Mapping radon-prone areas by lognormal modeling of house radon data. Health Physics, 74(3), New York: Lippincot Williams \& Wilkins, 1998, p 370-378.

12. Friis, L.; Carter, N.; Nordman, O.; Simeonidis, A.; Jardo $\mathrm{S}$. Validation of a geologically-based radon risk map: are the indoor radon concentrations higher in high-risk areas? Health Physics, 77(5), New York: Lippincot Williams \& Wilkins, 1999, p 541-544.

13. Abromaitytè, R.; Pilkytè, L.; Morkūnas, G. Radon risk investigation in Panevéžys city development area. Health Sciences, Vol 3. Vilnius: Sveikata, 2003, p 32-35 (in Lithuanian).

14. Morkūnas, G.; Pilkytè, L.; Plyčiuraitienè-Plyčienè, J.; Akerblom, G.; Clavensjo, B. Indoor radon. Remedial measures (Radonas patalpose. Jo kiekio mažinimo būdai), 2002. $16 \mathrm{p}$ (in Lithuanian).

15. Morkūnas, G.; Akerblom, G.; Pilkyte, L. Results of the Swedish and Lithuanian co-operation in protection from natural exposure. Health Sciences, Vol 2. Vilnius: Sveikata, 2002, p 80-84. 


\section{JONIZUOJANČIOJI SPINDULIUOTE் PATALPOSE: BŪKLE் IR PROBLEMŲ SPRENDIMO BŪDAI}

\section{Butkus, G. Morkūnas, L. Pilkytė}

\section{S a n tra u a}

Apšvitos dozè, tenkanti patalpose esantiems žmonėms, yra labai reikšminga tarp kitų gamtinių ir dirbtinių šaltinių nulemtų poveikio dozių. Svarbu ir šios dozès dydis, ir būtinybė ją optimizuoti. Svarbiausieji apšvitos šaltiniai patalpose yra radonas ir gamtiniai radionuklidai statybinèse medžiagose. Lietuvoje atliktų radono tūrinio aktyvumo patalpose matavimų rezultatai rodo, kad šis aktyvumas kai kuriuose regionuose gali būti gana didelis ir kad dažnai pagrindinis radono šaltinis patalpose yra gruntas. Radono šaltinis patalpose gali būti ir statybinès medžiagos, tačiau kur kas didesnès reikšmès turi išorinè statybinèse medžiagose esančių radionuklidų nulemta žmogaus apšvita. Labai dažnai i gamtinę apšvitą nekreipiama dėmesio. Sprendžiant šią problemą, pagrindinès priemonès - informuoti visuomenę, laikytis radiacinès saugos ir statybos teisès aktų, mažinti radono tūrinị aktyvumą patalpose. Svarbu radiacinę saugą optimizuoti.

Raktažodžiai: spinduliuotè, gamtinè apšvita, radonas patalpose, statybinès medžiagos, radiacinès saugos optimizavimas, radono tūrinio aktyvumo mažinimo priemonès.

Donatas BUTKUS. Dr Habil, Prof, Dept of Environmental Protection, Vilnius Gediminas Technical University (VGTU), Saulètekio al. 11, LT-10223 Vilnius-40, Lithuania. E-mail: aak@ap.vtu.lt

Doctor Habil of Science (environmental engineering), VGTU, 1999. Membership: Member of International Academy of Ecology and Life Protection. Publications: author of more than 100 research papers, co-author of the monograph "Geophysical problems of atmospheric krypton-85" (in Russian and English). Research interests: accumulation of radioactive noble gases, their interaction with environmental bodies, self-cleaning of the atmosphere, influence of ionizing radiation of radioactive noble gases on geophysical processes; investigation of the consequences of the Chernobyl accident in Lithuania.

Gendrutis MORKŪNAS. Dr, Dept of Programs and Expertise, Radiation Protection Centre, Kalvariju 153, LT-08221 Vilnius, Lithuania, e-mail: genmo@takas.lt.

Publications: author and co-author of more than 70 research papers and books. Research interests: radiation protection, natural and medical exposure, indoor radon, dose assessment techniques, optimization problems in radiation protection.

Laima PILKYTE். Doctoral student (since 2002), Dept of Environmental Protection, Vilnius Gediminas Technical University (VGTU), Sauletekio al. 11, LT-10223 Vilnius-40, Lithuania. Engineer radiologist, Dept of Programs and Expertise, Radiation Protection Centre, Kalvarijų g. 153, LT-08221 Vilnius-42, Lithuania. E-mail: 1.pilkyte@rsc.lt

First degree in Physics, Faculty of Physics, Vilnius University, 1985. Publications: author (with co-authors) of 10 research papers in Lithuanian and foreign journals. Research interests: natural radioactivity in environment, assessment of internal and external exposure dose to ionizing radiation to general public, gamma spectrometry of building materials and environmental samples, indoor radon. 